\title{
A HADFELSZERELÉSI IGÉNYEK TERVEZÉSE ÉS BIZTOSÍTÁSA A KÜLÖNLEGES JOGRENDI IDŐSZAK BEVEZETÉSEKOR
}

\author{
DOI: $10.35926 / \mathrm{HSZ} .2021 .6 .8$
}

ÖSSZEFOGLALÓ: A különleges jogrendi időszak bevezetésekor a Magyar Honvédség számára rendkivül fontos, hogy a kiadott parancsok, intézkedések, rendeletek, feladatok hatékony végrehajtásához megfelelő mennyiségü és minőségü anyagokkal, eszközökkel és jól kiképzett, szakmailag felkészült állománnyal rendelkezzen. A hadfelszerelési igények tervezése alapvetően békeidőszakhoz köthető tevékenység, amelyben kiemelt jelentöséggel bír, hogy a készletek, haditechnikai eszközök számvetése a pontosságot, a precizitást tükrözze. A jól megalapozott és megfelelöen alátámasztott igények egy része már a békeidőszakban is rendelkezésére áll a haderőnek, mig a hiányzó, fennmaradó termékek, cikkek később, egyes nemzetgazdasági szereplök bevonásán keresztül, elözetes szerződések megkötésével jutnak el a felhasználóhoz, a Magyar Honvédséghez. A cikkben - a teljesség igénye nélkül-a szerző áttekinti a hadfelszerelési igények tervezését és azokat a folyamatokat, elemeket, amelyek biztosithatják a felmerülő szükségletek kielégítését, kitérve a lehetséges kockázatokra is.

KULCSSZAVAK: logisztikai támogatás, hadfelszerelés, különleges jogrendi időszak, nemzetgazdaság, készletképzés

A Magyar Honvédség ( $\mathrm{MH}$ ) legfontosabb feladatait az alaptörvény rögzíti. Eszerint a honvédség ,....alapvetö feladata Magyarország függetlenségének, területi épségének és határainak katonai védelme, nemzetközi szerzödésböl eredö közös védelmi és békefenntartó feladatok ellátása, valamint a nemzetközi jog szabályaival összhangban humanitárius tevékenység végzése.” A feladatok eredményes végrehajtásához a haderőnek a mai kornak megfelelő, modern hadfelszerelésre és jól képzett, szakmailag felkészült állományra van szüksége.

Az $M H$ részéről felmerülő hadfelszerelési igények mindig igazodnak a magyar kormány és az Országgyűlés által meghatározott küldetésekhez, célokhoz (ideértve a szövetségi kötelezettségekből adódó feladatokat is). A hadfelszerelési igények tervezése alapvetően békeidőszakhoz köthető tevékenység, amelynek végrehajtásában a csapattagozattól egészen a stratégiai szintig különböző katonai szervezetek vesznek részt.

A hadfelszerelés egy része (például harcjárművek, kézi- és komplex fegyverek, repülőgépek stb.) már békeidőszakban is rendelkezésére áll a haderőnek, míg a hiányzó anyagokat és eszközöket (élelmezési anyagok, üzemanyagok hadászati készletei stb.) később, a különleges jogrend bevezetésekor szerzik be a felelős szervek és személyek.

1 Magyarország Alaptörvénye 45. cikk (1). https://net.jogtar.hu/jogszabaly?docid=a1100425.atv (Letöltés időpontja: 2021. 01. 29.) 
A lebiztosítandó anyagok és eszközök a nemzetgazdaságon keresztül jutnak el az MHhoz meghatározott ipari kapacitások kihasználásával. Ezért is van szükség pontos adatokra az igényekről, mert a gazdasági szereplők fogják majd szerződéseken keresztül garantálni, hogy az egyes hadfelszerelések a meghatározott időben az MH rendelkezésére álljanak.

A védelemgazdasági alapterv azt a célt szolgálja, hogy információval rendelkezzünk a gazdaság kapacitásairól. A felelős szervek ennek alapján teszik meg a szükséges lépéseket annak érdekében, hogy a különleges jogrend bevezetésekor az igények kielégítése zökkenömentesen történjen.

A feladatok teljesítéséhez szükséges készletek megléte vagy a hiányzó anyagokra és eszközökre vonatkozó szerződések megkötése egyre nagyobb jelentőséggel bír napjainkban. A biztonságpolitikai helyzetben beállt változások (például az Oroszország által végrehajtott nagyszabású mozgósítások, a Krím annektálása, az arab tavasz utáni instabil helyzet stb.) arra késztették a NATO-t és a szervezet tagjaként Magyarországot, hogy a müveleti jelleg helyett az erők alkalmazási képességére, azaz a készenlét fejlesztésére helyezzék a hangsúlyt. ${ }^{2}$ Ennek megfelelően a gazdaságmozgósítással kapcsolatos tervek naprakész nyilvántartására, a különleges jogrend bevezetésekor jelentkező szükségletek kielégítésére is kiemelt figyelmet kell fordítani.

Tanulmányomban - a teljesség igénye nélkül - dokumentumok elemzése alapján igyekszem bemutatni:

- a készletképzési elveket;

- az MH részéről a különleges jogrendi időszakban jelentkező feladatok ellátásához összeállítandó hadfelszerelési igényt;

- a gazdaság lehetséges szerepeit a szükségletek kielégítésében;

- azokat a kockázatokat, amelyek a gazdaságmozgósítás végrehajtásakor jelentkezhetnek.

\section{A HADFELSZERELÉSI IGÉNYEK TERVEZÉSE A KÜLÖNLEGES JOGRENDI IDŐSZAK FELADATAINAK ELLÁTÁSÁHOZ}

A hadfelszerelés meghatározására az 52/2020 (X. 8.) HM utasításban a következő definíció olvasható: „,... a honvédelmi szervezetek tevékenységéhez szükséges valamennyi olyan termék, amelyet az ipar és a kereskedelem katonai célokra gyárt vagy szállít, valamint a polgári kereskedelmi forgalomba nem, vagy csak külön engedéllyel kerülhet, és a beszerzését jogszabály szabályozza, továbbá mindazon hardver-és szoftvertermék, amelynek katonai alkalmazásba vétele tervezett." "3átható, hogy az MH részére történő hadfelszerelés gyártása, elöállítása vagy szállítása a civil szféra, valamely iparág hozzájárulásával valósul meg. Természetesen csak olyan eszköz, anyag kerülhet a haderőhöz, amely átesett rendszeresítési eljáráson és megfelel a szakemberek által meghatározott paramétereknek, müszaki követelményeknek. A jelen írásban főként a már rendszeresített hadfelszerelés készletképzésével és a megállapított hiányok biztosításának lehetőségeivel foglalkozom.

Horváth Attila: A katonai logisztika alapképzési szak RSOM felkészítés tapasztalatai. Hadmérnök, XIII. évf./ 2018/4., 82. http://hadmernok.hu/184_06_horvath.pdf (Letöltés időpontja: 2021. 01. 30.)

3 A honvédelmi miniszter 52/2020. (X. 8.) HM utasítása a hadfelszerelés rendszerbe kerülésének és rendszerből történő kivonásának rendjéről. https://magyarkozlony.hu/dokumentumok/1ce0b56bed728b91 faaaeaa1c0093434 3bb6287c/megtekintes (Letöltés időpontja: 2021. 02. 02.) 
A hadfelszerelési igények tervezése ${ }^{4}$ már csapatszinten elkezdődik, amelyhez szükséges a tervező személyeknek (a különböző anyagnemfelelősöknek, szakterület-vezetőknek) ismerni és használni a hadi- és üzemeltetésinorma-előírásokat, a hadi állománytáblát, a lépcsőzési elveket, a tárolási szabályokat, az alap Logisztikai Információs Rendszert ${ }^{5}$ (aLOGIR) és a jelentések rendszerét. Az említett szabályzókat, intézkedéseket általában minősített adatokként tartják nyilván, így csak korlátozott mértékben lehet utalni rájuk és ismertetni az azokban tárolt információkat.

A meglévő és hiányzó készletek megállapításához egy táblázatot szükséges kitölteni. A hadfelszerelési táblázatban szerepelnek a készletekre vonatkozó pontos megnevezések, a személyekre, eszközökre és a csapatanyagraktárak után számvetett szükségletekre vonatkozó, különböző mértékegységekben (például kilogramm, darabszám, liter) kifejezett információk. A kitöltéshez szükséges beazonosítani, hogy az adott hadfelszerelés mely anyagnemhez tartozik. Ezt legkönnyebben az MH parancsnoka által kiadott M/22/55/53 és a 4915-1/2020 nyilvántartási számú, a Magyar Honvédség Készletképzési és Készletlépcsőzési Rendjében, valamint Hadinormájában (I. és II. kötet) szereplö iránymutatások alapján lehet végrehajtani. Ezek alapján a hadinormában 5 anyagosztály (I-V.) szerint különböztetik meg az anyagokat és eszközöket, amelyek a következők: ${ }^{6}$

- I. osztály: azok a cikkek és anyagok, amelyeket a személyi állomány vagy állatok megközelítőleg azonos mennyiségben fogyasztanak (élelmiszer, takarmány stb.).

- II. osztály: azon hadfelszerelés, amelynek mennyiségét (javadalmazását) a szervezeti és eszközállománytáblák határozzák meg (például ruházati cikkek, alkatrészek, szerszámkészletek stb.).

- III. osztály: a hajtó- és kenőanyagok, kivéve a repülőeszközök üzemanyagai. (III./a osztály: a repülöeszközök hajtó- és kenőanyagai.)

- IV. osztály: építési és erődítési anyagok, telepített berendezések (például szögesdrótok, homokzsákok stb.).

- V. osztály: lőszerek, robbanóanyagok, kémiai hatóanyagok (például bombák, gyutacsok, detonátorok, rakéták, hajtótöltet stb.).

A hadfelszerelés megkülönböztetése mellett az általános elveknél meghatározzák, hogy a szükségleteket Átlagos Napi Ellátási Normában (Standard Day of Supply - SDOS) kell megállapítani, amely a felhasználókra (személyekre, eszközökre) számvetett közepes intenzitású mủveleti nap ellátási igényét tartalmazza. Továbbá, hogy a készletek megalakítása szerint a katonai szervezeteket három $(\mathrm{A}, \mathrm{B}, \mathrm{C})$ ellátási kategóriába sorolják attól függően, hogy milyen feladatokat (ti. harcoló, harctámogató vagy harckiszolgáló-támogató) látnak el a különböző müveletek végrehajtásakor. A készleteket lépcsőzve - csapatszinten 7 DOSnak, míg központi szinten 23 DOS-nak megfelelő mennyiséget - szükséges megalakítani.

\footnotetext{
4 A hadfelszereléseket és ebből adódóan az igények tervezését, valamint a készletek képzését alapvetően két részre lehet bontani: a hadianyagokra (harcanyagok, fenntartási anyagok, ellátási anyagok) és a haditechnikai eszközökre (harceszközök, biztosítóeszközök, kiszolgálóeszközök).

5 „Az alap Logisztikai Információs Rendszert 2019-ben állították rendszerbe, amely teljes egészében kiváltotta a korábbi eszközanalitikus nyilvántartást. Az új rendszert az SAP (Systemanalyse und Programmentwicklung: Rendszerelemzés és Programfejlesztésplatformok) részeként sikerült kifejleszteni, amely illeszkedik a már meglévő HM Központi Költségvetés és Gazdálkodási Rendszerhez (HM KGIR) és az SAP-Egészségügyi Központ rendszeréhez (SAP-EK).”Szajkó Gyula - Dr. Fábos Róbert: Gondolatok a katonai ellátási lánc fejlesztési lehetőségeiröl. Katonai Logisztika, 2020/1-2., 172. http://epa.oszk.hu/02700/02735/00091/pdf/EPA02735 katonai_logisztika_2020_01-02_151-181.pdf(Letöltés időpontja: 2021. 02. 02.)

6 Ált/217. Magyar Honvédség Összhaderőnemi Logisztikai Támogatás Doktrína (3. kiadás). Budapest, Magyar Honvédség, 2015, 67.
} 
Így az MH részére, feladatainak teljesítésére 30, közepes intenzitású harcnapra számvetett, illetve a felhasznált anyagok, eszközök utánpótlására 15 napos „nemzetgazdasági induló készletet" kell biztosítani. ${ }^{7}$ Az 1. táblázat az üzemanyagokra vonatkozóan (példaként) egy egyszerüsített számvetést tartalmaz, amely a készletek megalakítását hivatott szemléltetni.

1. táblázat Eszközök hajtóanyag-szükségleti számvetése (Szerkesztette a szerzö)

\begin{tabular}{|l|l|l|l|l|l|l|}
\hline $\begin{array}{l}\text { Eszköz } \\
\text { megnevezése }\end{array}$ & $\begin{array}{l}\text { Eszköz } \\
\text { hajtóanyag } \\
\text { tartály- } \\
\text { készlet }\end{array}$ & $\begin{array}{l}\text { 1 napi } \\
\text { szükséglete } \\
\text { (ÜZA/7 } \\
\text { alapján }\end{array}$ & $\begin{array}{l}7 \text { napi } \\
\text { szükséglete } \\
\text { (DOS) }\end{array}$ & $\begin{array}{l}\text { Tartály- } \\
\text { kiegészítő } \\
\text { készlet }\end{array}$ & $\begin{array}{l}\text { 23 napi } \\
\text { szükséglet } \\
\text { (DOS) }\end{array}$ & $\begin{array}{l}\text { ÖSSZESEN } \\
\text { (DOS) }\end{array}$ \\
\hline PSZH BTR/80 & $\begin{array}{l}300 \text { liter } \\
\text { téli gázolaj }\end{array}$ & 49 liter & 343 liter & 60 liter & 1127 liter & 1487 liter \\
\hline Audi A6 2.4 & $\begin{array}{l}70 \text { liter } \\
\text { Esz-95 } \\
\text { autóbenzin }\end{array}$ & 11,4 liter & 79,8 liter & 20 liter & 262 liter & 422 liter \\
\hline
\end{tabular}

A táblázatban látható, hogy az eszközök 1 napi szükségletét a gép fogyasztási normája alapján számoltam ki, és azt szoroztam meg az ellátási napok számával. Amennyiben az eszköz tartálykészletének befogadóképessége nem elegendő a 7 napi készlet tárolására, úgy tartálykiegészítő készletet kell megalakítani, amelyet mennyiségtől függően 20 literes üzemanyagkannában vagy 200 literes acélhordóban szükséges lebiztosítani. Egy harcjármü (jelen esetben: PSZH BTR/80) után téli gázolajból 360 liter (7 DOS) csapatkészletet és 1127 liter központi készletet indokolt megalakítani. Ha egy dandárszintủ szervezet rendelkezik megközelítőleg 240 darab PSZH BTR/80 típusú harcjármüvel, akkor helyszínen 86400 liter, míg központi tagozatnál 270480 liter téli gázolajnak megfelelő mennyiséget célszerü lebiztosítani annak érdekében, hogy a katonai szervezet megfeleljen a készletképzés elöírásainak. A hadfelszerelési táblázatban tehát a rovatokat kitöltik a számvetett szükségletekkel, a helyszínen lebiztosítható, valamint a központi tagozatnál tárolandó készletekkel.

Természetesen anyagnemenként specifikusan változhat a számvetések módszere. Vannak például olyan hadfelszerelések (föként haditechnikai eszközök), amelyek DOS-ban nem kifejezhetőek, ezért azokat százalékban és/vagy darabszámban állapítják meg a katonai szervezetek. Itt csak a példa alapján azt kívántam szemléltetni, hogy a hadfelszerelési igények (szükségletek) tervezése a szabályok szerint, szigorú elöírások, normatívák betartásán keresztül valósul meg a honvédség részéröl.

A katonai szervezetek az említett dokumentumok alapján tehát összeállítják az összes hadfelszerelésre vonatkozó igényüket, amelyet továbbítanak az elöljáró tagozat felé. Mindezek alapján az elöljáró tagozat (MH Parancsnoksága, MH Tartalékképző és Támogató Parancsnokság) megállapítja az MH összesített hadfelszerelési szükségletét, és a pótlás biztosítására megküldi igényét a Honvédelmi Minisztérium részére. A honvédelmi tárca az MH különleges jogrend időszaki igényét átadja az Innovációs és Technológiai Minisztériumnak a védelemgazdasági alapterv összeállításához.

Uo. 118 .

A szárazföldi eszközök hajtóanyag-alapnormáit az ÜZA/7 szabályzat tartalmazza. Az egynapi hajtóanyagkészletet a NATO 2115 (Üzemanyag Fogyasztási Egység) szabványban meghatározottak szerint állapítják meg. A táblázatban szereplő eszközöknél az egynapi készletet a következők szerint számoljuk: 100 km megtételéhez szükséges mennyiség száraz, vízszintes, szilárd burkolatú úton, közepes terheléssel, közepes sebességgel, a gép hajtóanyagfogyasztási normája szerint. 
Az igények teljesítéséről a lebiztosítási szerződésen keresztül határozat is készül, amelyröl (a nemzetgazdaságból biztosított haditechnikai eszközök vonatkozásában) tájékoztatást kapnak az érintett szervezetek az elöljáró tagozatoktól és az MH Katonai Igazgatási és Központi Nyilvántartó Parancsnokságtól. A folyamatot az 1. ábra szemlélteti.

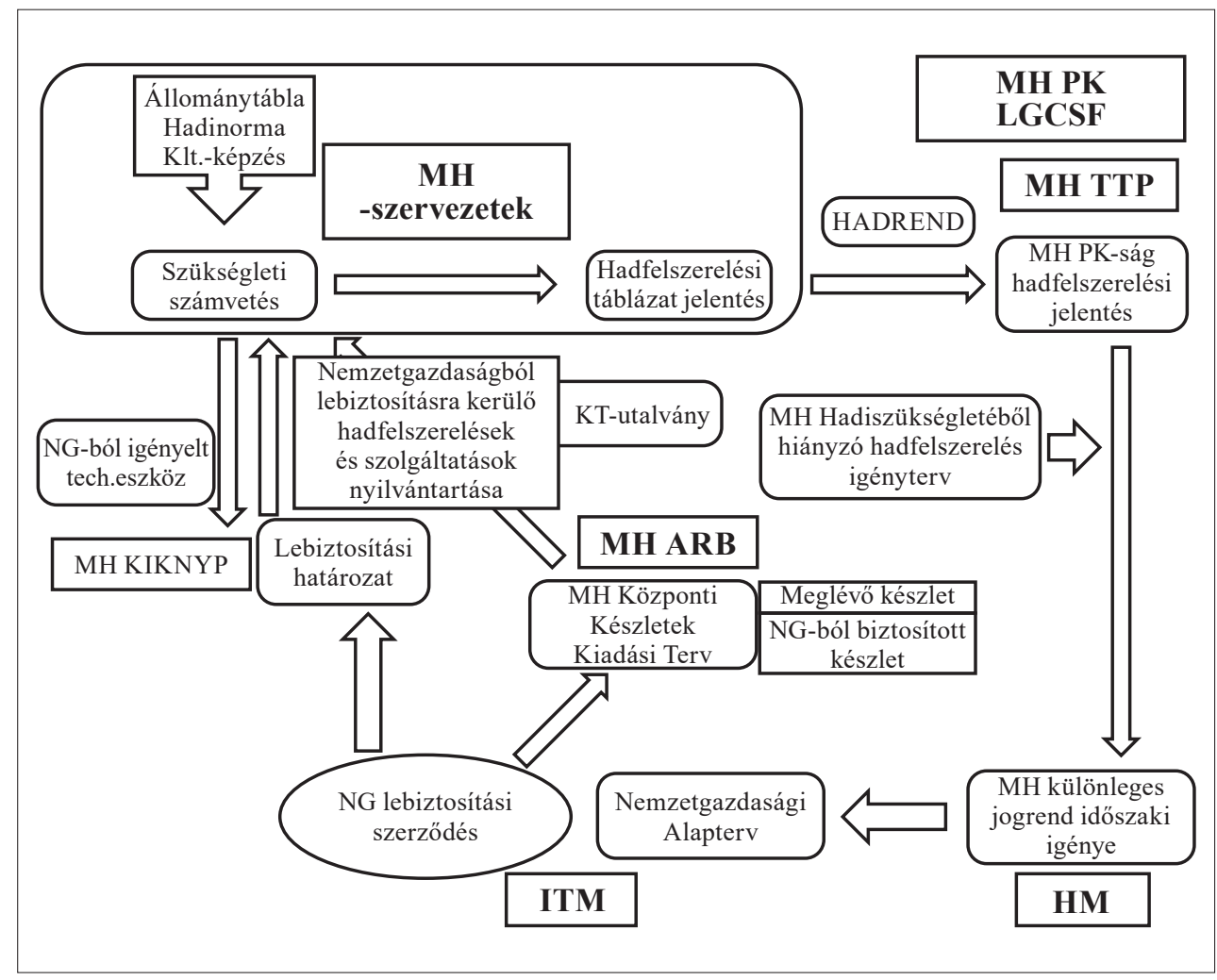

1. ábra A hadfelszerelési igény tervezésének folyamata (Szerkesztette a szerzö)

Az ábra magyarázatához hozzátartozik, hogy a katonai szervezetek a 7 DOS szükségleteiből a helyszínen nem tárolható készletekre vonatkozóan (például tárolóhely-kapacitás hiánya miatt) Központi Tárolási Utalványt (KTU) is kérhetnek a magasabbegységek engedélyével, hogy az anyagok és eszközök egy meghatározott részét a központi raktárakban (MH Anyagellátó Raktárbázis - MH ARB) biztosítsák. Az MH ARB a helyszínen nem tárolt készletekről felterjeszthet igényt az elöljáró felé, hogy a hiányzó anyagok és eszközök rendelkezésre állása a nemzetgazdaság hozzájárulásával valósuljon meg.

Látható, hogy a különleges jogrendi időszaki feladatok végrehajtását garantáló hadfelszerelés tervezése és biztosítása összetett folyamat. A nemzetgazdaság tehát meghatározó szerepet tölt be az anyagok és eszközök tekintetében a szükségletek kielégítésében. A különleges jogrendi időszak bevezetésekor jelentkező feladatok a kihirdetett állapottól függően különbözőek lehetnek. Ennek megfelelően krízisidőszakban változhatnak a honvédség részéről jelentkező szükségletek is. Nyilvánvalónak tünik, hogy rendkívüli állapot kihirdetésekor intenzív müveleteket kell végrehajtania az MH-nak, míg veszélyhelyzet időszakában ennél jóval kevesebb feladat hárul a haderőre. Így célszerü megemlíteni, melyek azok a helyzetek, 
állapotok - a jelenleg érvényben lévő törvény szerint -, amelyek bekövetkezésekor a különleges jogrend elrendelhető, kihirdethető. Ezek lehetnek: ${ }^{9}$

- rendkivüli állapot: ha az Országgyülés kinyilvánítja a hadiállapotot vagy idegen hatalom fegyveres támadásának közvetlen veszélye áll fenn (háborús veszély) és honvédelmi tanácsot hoz létre;

- szükségállapot: ha a rendőrség és a nemzetbiztonsági szolgálatok alkalmazása nem elegendő a rend, a közbiztonság fenntartására;

- megelöző védelmi helyzet: amikor az Országgyülés külső fegyveres támadás veszélye esetén vagy szövetségi kötelezettség teljesítése érdekében meghatározott időszakra kihirdeti a megelőző védelmi helyzetet, ezzel egyidejüleg felhatalmazza a kormányt sarkalatos törvényben meghatározott rendkívüli intézkedések bevezetésére;

- terrorveszélyhelyzet: ha terrortámadás jelentős és közvetlen veszélye áll fenn, vagy terrortámadás történt;

- váratlan támadás: amikor külső fegyveres csoportoknak Magyarország területére történő váratlan betörése esetén a támadás elhárítására, Magyarország területének a honi és szövetséges légvédelmi és repülő készültségi erőkkel való oltalmazására, a törvényes rend, az élet- és vagyonbiztonság, a közrend és a közbiztonság védelme érdekében a kormány kihirdeti a váratlan támadást, és szükség esetén - a szükségállapot vagy a rendkívüli állapot bevezetéséig - a támadással arányos és arra felkészített erökkel a köztársasági elnök megteszi a szükséges ellenlépéseket;

- veszélyhelyzet: ha az élet- és vagyonbiztonságot veszélyeztető elemi csapás, vagy ipari szerencsétlenség következik be.

Látható, hogy a felsorolt állapotok bevezetésekor az MH-nak meghatározott feladatai lesznek, amelyek végrehajtásához megfelelö mennyiségü és minőségü anyagokra, eszközökre van szüksége. A nemzetgazdaságnak a különleges jogrend időszakában (ez különösen igaz a rendkívüli állapot kihirdetésekor) fel kell készülnie arra, hogy a haderő részére elegendő hadfelszerelést biztosítson a feladatok teljesítéséhez. Ennek megfelelően szükséges kijelölni és pontosan nyilvántartani azokat a nemzetgazdaságban meglévő vagy kiépítendő kapacitásokat, amelyekkel mindez garantálható.

\section{A NEMZETGAZDASÁG SZEREPE A HADFELSZERELÉS BIZTOSÍTÁSÁBAN. \\ A TERMELÉST ESETLEGESEN BEFOLYÁSOLÓ KOCKÁZATI TÉNYEZÖK}

A nemzetgazdaság felkészítésével és mozgósításával érhető el, hogy az a különleges jogrendi időszaki feladatokhoz a haderő részéről jelentkező igényeket kielégítse. Az anyagok, eszközök előállítására, biztosítására alapvetően az alábbi módszerek állnak rendelkezésre: ${ }^{10}$

- Igénybevétellel történő igénykielégités: idetartoznak a nemzetgazdaságban meglévő és honvédelmi vagy védelmi célból kijelölt ingatlanok (például hírközlési, közlekedési, infrastrukturális hálózatok), ingó dolgok (például közúti, vízi, légi jármüvek, vasúti gördülöanyagok).

\footnotetext{
9 Magyarország Alaptörvénye, 42-47.

10 131/2003. (VIII. 22.) Korm. rendelet a nemzetgazdaság védelmi felkészítése és mozgósítása feladatai végrehajtásának szabályozásáról. https://net.jogtar.hu/jogszabaly?docid=a0300131.kor (Letöltés időpontja: 2021. 02. 10.)
} 
- Folyó termelö és meglévő készletek kapacitásai: azok az erőforrások, amelyeket hazai termelő, szolgáltató kapacitásokon állítanak elő, vagy amelyeket belföldi gazdasági társaságok, szervezetek forgalmaznak, feltéve, hogy a gazdaságmozgósítási igény megfelelő mennyiségben és minőségben kielégíthetőnek minősíthető. Ebbe a csoportba tartozhat a folyamatosan forgalmazott polgári termékek többsége (például energiahordozók, az élelmiszerek, mezőgazdasági termékek, hazai gyártású gyógyszerek), a társaságoknál készletezett anyagok (például üzemanyagok), vagy a szolgáltatásokhoz és termékekhez szükséges alapanyagok, fogyasztási cikkek és egyes gyártó/javító kapacitások.

- Védelmi célú tartalékokból történő igénykielégités: a gazdasági erőforrás biztosítása megvalósítható az előállítási ciklus különböző fázisainak (kész- vagy félkész termék, nyersanyag, gyártóeszköz) tartalékolásával és szükség esetén a félkész termékeknek a készre gyártásával.

- Rögzített hadiipari kapacitások: nagy tömegben alkalmazott, honvédelmi vagy védelmi szempontból fontos termékféleségek gyártását, javítását biztosító kapacitásokat jelölnek ki és rögzítenek. A kapacitások folyó időszaki fenntartására a kormány - szerződés alapján - költségvetési erőforrást is nyújt a szolgáltatásra kötelezetteknek, amelyek gazdasági megfontolás és egyéb tényezők figyelembevételével eldönthetik, hogy a készterméket fizikailag készletezik és tárolják, vagy pedig a készre gyártó kapacitásokat szerződéssel rögzítik, esetleg a kettő kombinációját alkalmazzák; vállalják továbbá az anyagok és eszközök minősített időszakban történő rendelkezésre állását a vonatkozó szerződéskötési kötelezettségeknek megfelelően.

- export-importból történő igénykielégités: az a) és b) pontokban felsorolt igénykielégítési módokkal nem biztosítható erőforrásra importbeszerzési eljárást szükséges lefolytatni, tekintettel arra, hogy veszélyeztetettségi időszakban (6 hónap) akár exportot korlátozó, importot könnyítő gazdaságpolitikai intézkedések bevezetését is elrendelheti a kormány.

\section{A védelemgazdasági alapterv}

A nemzetgazdaság védelmi célú felkészítése békeidőszakhoz tartozó tevékenység, amelynek végrehajtásakor kiemelt jelentőséggel bír a védelemgazdasági alapterv összeállítása, naprakész nyilvántartása és vezetése. A védelemgazdasági alapterv révén érhető el, hogy a különleges jogrendi időszakban is hozzáférhetőek legyenek a hadfelszerelési igények kielégítését biztosító kapacitások. A dokumentumot a központi tervező szerv (ti. a mindenkori gazdaságpolitikáért felelős minisztérium) állítja össze a honvédelemben közremüködő intézmények adatszolgáltatásai alapján. ${ }^{11}$ Az alaptervet a tervezésért felelös minisztérium vezetője hagyja jóvá, aki köteles beszámolni minden évben a kormánynak a nemzetgazdaság védelmi célú felkészítéséröl.

A nemzetgazdasági alapterv külön fejezetekre tagolva készül el, amelyek kitérnek a követelménytámasztók által meghatározott különleges jogrendi időszaki igényekre, a szükségletek kielégítésére vonatkozó javaslatokra, a hozzá kapcsolódó költségvetési forrásokra és a szerződések előkészítésére, valamint megkötésére.

11 2011. évi CXIII. törvény a honvédelemről és a Magyar Honvédségről, valamint a különleges jogrendben bevezethető intézkedésekről. https://net.jogtar.hu/jogszabaly?docid=a1100113.tv (Letöltés időpontja: 2021. 02. 10.) 
Az első fejezetben - az MH és a rendvédelmi szervek igényein felül - tervet készítenek a nemzetgazdaság mozgósítására is. A szükségletek kielégítésére vonatkozó javaslatokat a jelen tanulmányban korábban leírt lehetséges módszerek figyelembevételével és a kapacitásokat biztosító szervezetek kijelölésével készítik el.

A harmadik fejezetben a költségvetési erőforrások tervezését két lépcsőben, egymással párhuzamosan, de folyamatosan egyeztetve végzik a felelős szervek. Az államháztartásért felelős miniszter, a gazdasági prognózisok alapján, a GDP előírt százalékában meghatározza az adott évben figyelembe veendő védelmi kiadások összesített nagyságrendjét s ezen belül az egyéb védelmi kiadásokat is. ${ }^{12}$ Ezzel párhuzamosan az erőforrások biztosításában érintett szervezetek megküldik költségvetési javaslataikat a honvédelemért felelős miniszternek, aki az összesített adatokat továbbítja az államháztartásért felelős miniszternek. Ha az összesített igény és az államháztartásért felelős miniszter által kimunkált főszámok nem felelnek meg egymásnak, akkor további egyeztetés következik, hogy a törvényjavaslatban már konszenzusos számadatok jelenjenek meg. Ezt követően az alapterv utolsó fejezetében a költségvetési források tervezésében érintett szervezetek előkészítik és megkötik a gazdaságfelkészítési és gazdaságmozgósítási szerződéseket. Elmondható, hogy a védelemgazdasági alapterv elkészítésével, az abban foglaltak betartásával elérhetővé válik, hogy a különleges jogrend bevezetésekor a haderő részéről jelentkező szükségleteket kielégítsék.

\section{A hadiipari termelésre történő átállás lehetséges kockázatai}

A gazdaság mozgósításakor fontos szerepet betöltő vállalatoknak különböző kockázatokkal kell szembenézniük, amikor átállnak hadiipari termelésre. Véleményem szerint szükséges beazonosítani ezeket a kockázatokat, és amennyiben lehet, megfelelő kezelést is érdemes alkalmazni, hogy a különleges jogrend bevezetésekor a termelés zökkenőmentesen történjen. A kockázatok feltárására, osztályozására és azok negatív hatásainak csökkentésére hozott ellenlépéseket a védelemgazdasági alapterv részeként vagy mellékleteként szükséges kidolgozni.

Minden, a nemzetgazdaság mozgósítását és felkészítését, a hadiipari termelést érintő kockázatról tájékoztatni kell az államháztartásért felelős minisztert, aki ennek függvényében dönthet arról, hogy vállalja-e a kockázatokat, vagy utasítja az érintett ágazati minisztériumokat, hogy dolgozzanak ki egy olyan tervet, ami minimumra csökkenti a lehetséges kockázatok bekövetkezésének valószínüségét. A kockázati tényezők feltárása hosszadalmas elemzést igényel, azonban elhagyása - véleményem szerint - extrém magas hatással lehet a hadiipari termelésre, így a hadfelszerelési igények időben történő kielégítésére is. A nemzetgazdaság mozgósítását és felkészítését érintő lehetséges kockázati tényezőket a 2. ábra mutatja be.

Az ábrán egy valószínüség-hatás diagram látható, amely osztályozás nélkül mutatja be az elöforduló kockázatokat és veszélyeket. Az elemzők feladata, hogy a feltárt és számmal jelölt szempontokat külön-külön, a bekövetkezés valószínüsége és a hadiipari termelésre gyakorolt lehetséges hatásuk alapján osztályozzák, és javaslatot tegyenek csökkentésükre.

A felsorolt kockázati tényezők listája bővíthető, itt csak a legáltalánosabb veszélyeket emeltük ki. A szempontok besorolása összetett és sokszor szubjektív mérlegelésen alapuló tevékenység, amelyben a békeidőszaki termelésnél szerzett tapasztalatok, elemzések adhatnak támpontot. Az elemzők által osztályozott tényezőket tehát felvezetik a diagram megfelelö pontjára, és nyíllal azonosítják azok bekövetkezési valószínúségének, illetve

12 131/2003. (VIII. 22.) Korm. rendelet, 21. 
hatásának erősödését vagy gyengülését. Az extrém magas besorolású tényezőkre kiemelt figyelmet kell fordítani, és lehetőség szerint még a békeidőszakban szükséges kezelésükre javaslatokat kidolgozni.

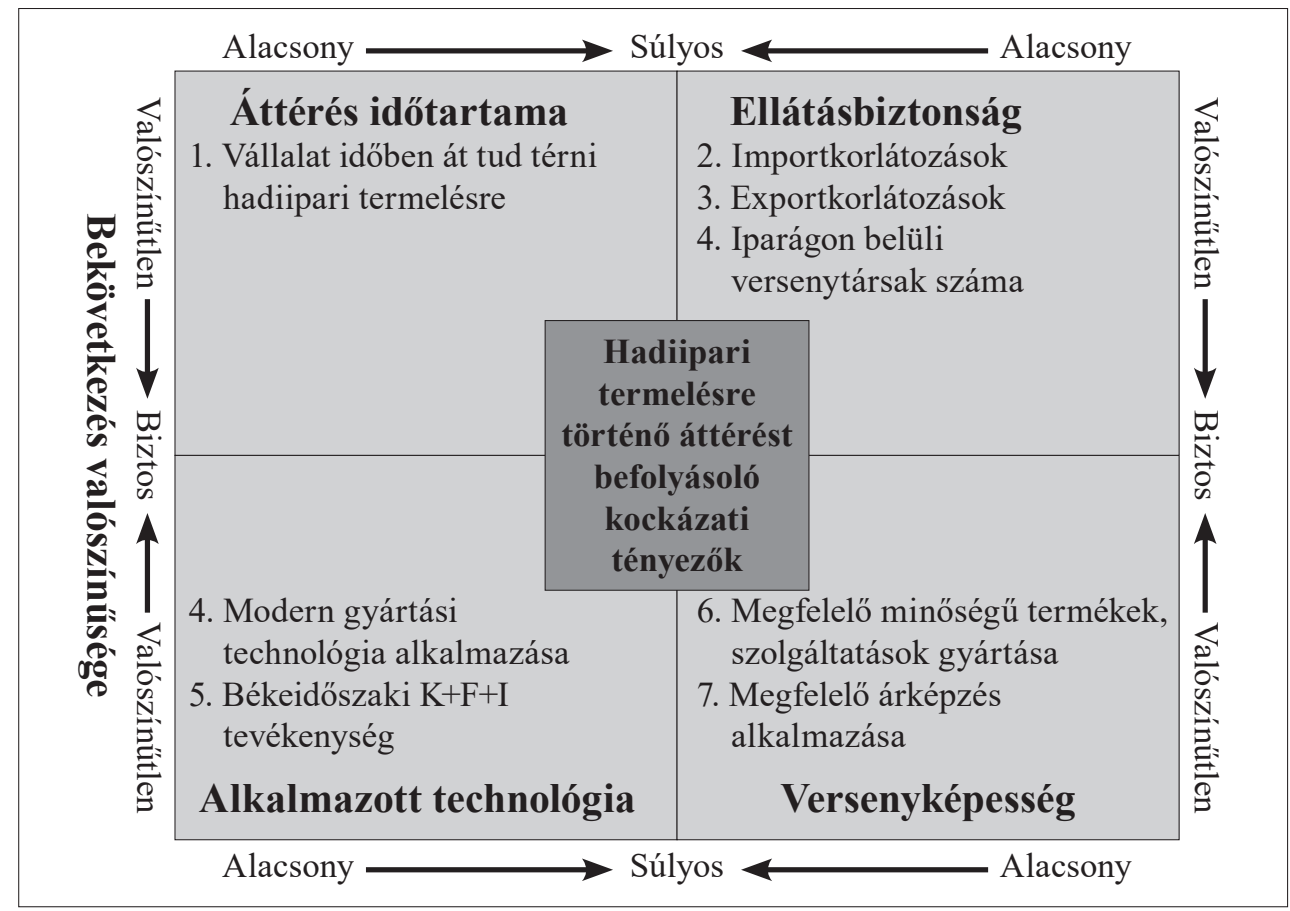

2. ábra Hadiipari termelésre történö áttérést érintő kockázati tényezők (Szerkesztette a szerzö)

Az ábrában felsorolt tényezők közül az ellátásbiztonság, az alkalmazott technológia és a versenyképesség már békeidőszakban is jelentős hatásokat gyakorolnak a hadiiparra. Ez a három összetevő egyben befolyásolhatja is az alábbi követelmények teljesülését: ${ }^{13}$

- mindig a kor technológiai színvonalát elérő eszközöket állítsunk elő;

- a hadiipar megfizethető, versenyképes áron állítsa elő termékeit, szolgáltatásait;

- képes legyen az ipar a haderő által alkalmazott haditechnikai eszközöket támogatni, valamint a gyártás/szolgáltatás folyamatát működtetni békeidőben és háborúban egyaránt.

Ezek a követelmények kockázatokat is rejtenek magukban, hiszen, ha nem a kor színvonalának megfelelő eszközöket állít elő a hadiipar, a hadsereg nem fogja tudni hatékonyan ellátni feladatát. A modern gyártási technológia és a békeidőszaki termelés minősége lehetővé teszi, hogy az ipar felkészüljön a nagy mennyiségü és korszerü hadianyag és haditechnikai eszköz biztosítására. Ehhez szükséges, hogy a vállalatok (különösen a létfontosságú termékeket és szolgáltatásokat előállítók) kutatás-fejlesztési tevékenységet is folytassanak, amelyhez az államnak is hozzá kell járulnia különböző támogatásokkal.

13 Taksás Balázs: A hadiipar fejlesztésének feltételei és működésének követelményei. Honvédségi Szemle, 148. évf. 2020/2., 130. http://real.mtak.hu/107697/ (Letöltés időpontja: 2021. 02. 16.) 
A kutatás-fejlesztésen és innováción keresztül a békeidőszakban is új anyagok, eszközök, gyártási technológiák elöállítása valósulhat meg, amely a különleges jogrend bevezetésekor is tovább müködhet. Rengeteg példa szemlélteti, hogy a háborúk idején is fejlett kutatásokat folytattak a konfliktusban részt vevő országok, hogy még modernebb eszközökkel szerelhessék fel hadseregüket az előny kivívása érdekében. ${ }^{14}$ A kutatás-fejlesztési tevékenységre fordított erőforrások csökkentése kockázatot jelenthet a létfontosságú termékeket és szolgáltatásokat előállító vállalatok és közvetetten a nemzetgazdaság számára, hiszen a tevékenység elmaradásával a gazdaság nem biztos, hogy fejlett, modern eszközökkel tudja majd ellátni a hadsereget (például) rendkívüli állapot kihirdetésekor. Ezért is fontos, hogy az állam támogassa (például szellemi tőkével, kutatást segítő eszközökkel vagy a projekt menedzselésével) azon vállalkozásokat, amelyek a nemzetgazdaság mozgósításakor kulcsszerepet töltenek be a kapacitások rendelkezésre állásában (például haditechnikai eszközt, energiahordozókat, élelmiszeripari termékeket előállító cégek). A kutatás-fejlesztési, innovációs tevékenységek „ösztönzésével” így elérhetővé válik, hogy a vállalkozások korszerü anyagokat, eszközöket biztosítsanak a haderőnek békeidőszakban és különleges jogrendi időszakban egyaránt.

A versenyképesség garantálhatja, hogy költséghatékonyan álljanak rendelkezésre az anyagok és eszközök. A hadsereg felszerelése mindig költséges feladat. Ez kifejezetten igaz a hadiiparra. Ha ugyanis a magyar vállalkozások drágábban állítanak elő terméket, szolgáltatást, mint a külföldi versenytársaik, akkor az adófizetőknek többet kell ráfordítaniuk ugyanakkora biztonság fenntartására, mint az érintett országok lakosságának. ${ }^{15}$ Ekkor, a magasabb árképzés miatt felmerülhet, hogy kevesebb hadfelszerelést vásárol az állam a hadseregének (ha nem kíván adót emelni, vagy más területektől erőforrást elvonni), amely a biztonság csökkenéséhez vezethet, és mérsékelheti a hadiipar profitszintjét is. Fontos tehát, hogy az iparágak megfelelő minőségü anyagokat, eszközöket állítsanak elő, és azokat elérhető áron bocsássák piacra, amellyel versenyképessé válhatnak akár a nemzetközi kereskedelemben is. Ha az iparágak exportálni tudják termékeiket, az azt jelenti, hogy nemcsak magas színvonalú technológiát állítanak elö, hanem képesek azt versenyképes áron biztosítani.

A versenyképes vállalkozások hiánya is kockázatokat rejt magában. Ha már békeidőszakban sem tud a hadiipar megfelelö minőségü terméket, szolgáltatást biztosítani elérhető áron, akkor valószínüsíthető, hogy a különleges jogrendi időszakban sem lesz erre képes, rosszabb helyzetben még állami segítséggel sem. Ezzel ellentétben a versenyképes vállalatok már megfelelö ár-érték aránnyal tudják termékeiket, szolgáltatásaikat értékesíteni a hazai és nemzetközi piacokon, amellyel növelhetik bevételüket, így nagyobb anyagi erőforrásokat tudnak fordítani fejlesztésekre, új technológiákra. Szükséges tehát elemezni, hogy a létfontosságú vállalatok mennyire versenyképesek, illetve megvizsgálni az ebből fakadó kockázatokat, hogy milyen hatással lehetnek ezek az igények kielégítésére.

\section{Az ellátásbiztonság}

Az ellátásbiztonság szintén alapvető tényező, hiszen a hadsereg számára rendkívül fontos, hogy a gazdaság mind krízis-, mind békeidőszakban képes legyen kielégíteni szükségleteit. Ez egyaránt jelenti a legyártott és értékesített eszközök alkatrész-utánpótlásának, a fogyó anyagi készletek kiegészítésének biztosítását és a folyamatos termelöképesség fenntartását. ${ }^{16}$

\footnotetext{
${ }^{14}$ Barton C. Hacker: Marslakók új környezetben. Az amerikai katonai kutatás és fejlesztés szervezeti átalakítása. Fizikai Szemle, Budapest, 1997/3., 88.

15 Taksás: i. m. 132.

${ }^{16}$ Uo.
} 
A béke- és a krízisidőszaki termék-előállítás nem biztos, hogy ugyanazon értékláncok müködtetésén keresztül fog megvalósulni. A különleges jogrend bevezetésekor elképzelhető, hogy az import- vagy exportkorlátozások kedvezőtlenül befolyásolják a vállalkozások müködését. Az importkorlátozások (például) nemcsak a magyarországi kőolaj-feldolgozásban érintett cégek termelési mennyiségét csökkenthetik, hanem megakadályozhatják (minimális tartalékkészlet hiánya esetén) magát az üzemanyag előállítását is. Könnyen belátható, hogy az Oroszországból érkező nyers kőolaj importjának korlátozása esetén jelentős fennakadások jelentkezhetnek az ellátásban. ${ }^{17} \mathrm{Ez}$ is kockázatot rejt magában, és szükséges megvizsgálni bekövetkezésének valószínűségét, majd biztonsági lépésként esetleg meghatározni azokat a minimális tartalékkészleteket, amelyeket állami segítséggel a cégek le tudnak biztosítani a különböző tárolóhelyeken.

Az importfüggőség természetesen kihathat alap- és félkész termékekre is, amelyeket a vállalatok külföldi gazdasági szereplőktől szereznek be a késztermékek előállításához; ez szintén kockázatokat jelenthet a létfontosságú anyagok, eszközök különleges jogrend időszaki gyártásakor.

Az iparágon belüli versenytársak száma szintén meghatározhatja a szükségletek kielégítésének gyorsaságát. Az amerikai védelmi minisztérium például azzal a kihívással találta szemben magát, hogy a precíziós irányítású rakéták előállításában részt vevő két hazai cég nem biztos, hogy krízisidőszakban képes lesz kielégíteni a hadsereg szükségleteit. Ezért azt a megoldást választották, hogy felépítenek egy olyan adatbázist, amelyen keresztül elemezhető a jelenlegi beszállítók helyzete, az ellátási láncok, a szükségletek, a termelőkapacitások, a helyettesíthető termékek és vállalkozások. Az elemzés hozzásegíti a döntéshozókat, hogy könynyebben azonosítsák a felmerülő kockázatokat, majd megtegyék a szükséges ellenlépéseket. ${ }^{18}$

Az iparági versenytársak számának növelésével csökkenteni lehet a korábban leírt kockázatokat. Ha elegendő vállalat van a piacon, kevésbé valószínü, hogy fennakadások lennének a hasonló vagy helyettesíthetö termékek, szolgáltatások biztosításában.

Az exportkorlátozások a nemzetgazdaság felkészítésekor érinthetik kedvezőtlenül a vállalatokat, hiszen ekkor a profit egy részéről kell lemondaniuk (ti. ha külföldre is értékesítenek termékeket, szolgáltatásokat) úgy, hogy közben a termelésüket fokozniuk kell, vagy változatlan szinten tartaniuk a különleges jogrend időszaki igények kielégítésére. Az államnak tehát fedeznie kell a vállalatok kieső bevételeit, hogy továbbra is változatlan színvonalon tudják termékeiket, szolgáltatásaikat előállítani.

Nyilvánvalóan a vállalatoknak - a lakossággal együtt - hozzá kell járulniuk az országvédelmi feladatokhoz (különösen rendkívüli állapot kihirdetésekor), akár lemondva bizonyos javakról vagy jövedelmekről/nyereségröl a legfelsőbb cél érdekében, figyelembe véve, hogy a végső ,átállásig” érdemes fenntartani a hatékonyság érdekében a vállalatok piaci alapú működését.

Az áttérés időtartama azoknál a vállalatoknál lehet fontos tényezö, ahol a termelökapacitást biztosító gyártóegységek, gyártósorok csökkentett teljesítménnyel müködnek békeidőszakban. A maximális kihasználás érdekében három időszakot lehet elkülöníteni, amelyek bevezetésével a vállalatok felkészülhetnek a teljes kapacitással történő üzemelésre: ${ }^{19}$

\footnotetext{
${ }^{17}$ Jelenleg az orosz államtól vásároljuk a nyers kőolaj szinte teljes mennyiségét. A magyar-orosz gazdasági kapcsolatok a XXI. század elején. Statisztikai Tükör, Budapest, 2010, 2. http://www.ksh.hu/docs/hun/xftp/gyor/jel/ jel31006.pdf (Letöltés időpontja: 2021. 02. 16.)

18 Julie C. Kelly et al.: Strengthening Industrial Base Decision-Making for Precision-Guided Munitions. Texas Security Review, 11. 08. 2020. https://warontherocks.com/2020/08/strengthening-industrial-base-decision-makingfor-precision-guided-munitions/?fbclid=IwAR2ZnW6MOOmX7EfNdefpneCqnyRadR3agStYHokYiGooNNEU 38cYUCDUfFc (Letöltés időpontja: 2021. 02. 12.)

19 Ált/217., 126.
} 
- felfutó periódusú termelés/szolgáltatás időszaka;

- a kapacitás maximális kihasználásának időszaka;

- helyreállítás időszaka.

A rögzített hadiipari kapacitásokkal rendelkező vállalatoknál tehát azt szükséges elemezni, hogy megelőző védelmi helyzet és rendkívüli állapot kihirdetésekor - amikor már folyamatosan kell biztosítani a termékeket, szolgáltatásokat - a vállalat készen áll-e a teljes kapacitással történő müködésre, vagy esetleg csak részleges üzemelésre lesz képes. Elegendő személyi állománnyal, eszközökkel rendelkezik-e, vagy szükség van állami beavatkozásra, segítségre.

Természetesen a létfontosságú vállalatokat (amelyeket kijelöltek) békeidőszakban adatszolgáltatási kötelezettség terheli, ha termelő-, szolgáltató kapacitásuk megszünik, 30\%-kal nő vagy csökken. Az információk alapján az állam még időben megteheti az elöírt lépéseket, amellyel a kulcsfontosságú kapacitások továbbra is fenntarthatók. Ezen túlmenően célszerü megvizsgálni, hogy amennyiben szükséges megnövelt személyi állomány, eszköz, technológia a maximális müködés eléréshez, és ez egyszerre több cégnél is jelentkezik, akkor az állam hogyan tudja ezeket biztosítani.

Látható, hogy a különleges jogrend bevezetésekor a nemzetgazdaságra különösen fontos szerep hárul a hadfelszerelési igények kielégítése terén. Fontos megjegyezni, hogy a nemzetgazdaság felkészítésekor és mozgósításakor nemcsak a hadsereget szükséges ellátni termékkel, szolgáltatásokkal, hanem az egész országot, tehát a lakosságot is. Ennek megfelelöen a nemzetgazdaságra többletteher hárul ebben az időszakban. Ezért is szükséges elemezni a felmerülő kockázatokat, amelyek hatással lehetnek az igények kielégítésére.

\section{ÖSSZEGZÉS}

A hadfelszerelési igények tervezése és a szükségletek meghatározása mindig szigorú előírások, intézkedések betartásán keresztül valósul meg a honvédség részéröl. A különleges jogrend bevezetésekor jelentkező feladatok ellátásához a hadsereg már békeidőszakban is rendelkezik alapanyagokkal, eszközökkel. A hiányzó felszereléseket a nemzetgazdaságból szükséges lebiztosítani szerződések útján, a védelemgazdasági alapterv jóváhagyásán keresztül. A honvédelmi tárca által összesített igényeken felül további 15 napos nemzetgazdasági indulókészletet kell megalakítani, és időben a haderő részéré átadni, amelynek teljesítéséhez szükség lehet a gazdaság mozgósítására is.

Természetesen a nemzetgazdaságnak a különleges jogrend bizonyos állapotaiban (különösen rendkívüli állapot kihirdetésekor) nemcsak a honvédség és a rendvédelmi szervek szükségleteit kell fedeznie, hanem az ország többi szereplőjének (köztük a teljes lakosságnak) az igényeit is szükséges kielégítenie. A védelemgazdasági alaptervben szereplö igénykielégítési módszerek (például folyó termelő és meglévő készletek kapacitásai, rögzített hadiipari kapacitások, védelmi célú tartalékok) megfelelö alapot képeznek a termékek és szolgáltatások biztosítására.

A hadiipari termelésre történő áttérés folyamata rejt magában kockázatokat, amelyek bekövetkezési valószínűségét érdemes vizsgálni és elemezni. Az áttérés időtartamához, az ellátásbiztonsághoz, az alkalmazott technológiához vagy a versenyképességhez tartozó tényezők jelentősen befolyásolhatják a nemzetgazdaság védelmi felkészítését, mozgósítását. Ha a hadiipari termelésben érintett vállalatok nem folytatnak kutatás-fejlesztési és innovációs tevékenységet, valószínü, hogy a modern eszközök gyártásában alulmaradnak a külföldi versenytársakhoz képest, és a hadseregnek sem tudnak megfelelő technológiai színvonalú 
hadfelszereléseket biztosítani. Amennyiben nem gyártanak a kor kihívásainak eleget tevő anyagokat, eszközöket, valószínü, hogy exportálni sem tudják azokat külföldre. Így csak a hazai piacon (különösen a hadiipar esetében) lesznek képesek értékesíteni termékeiket, szolgáltatásaikat, amellyel csökkenni fog bevételük, nyereségük, kutatás-fejlesztésre és innovációra visszafordítható tőkeállományuk.

Nyilvánvaló, hogy a nemzetgazdaság hadiipari termelésre történő áttérésekor az elsődleges szempont az, hogy a létfontosságú termékek, szolgáltatások rendelkezésre álljanak a szükséges helyen, időben, és az már csak másodlagos tényező, vagy egyáltalán nem számít, hogy a vállalat mennyire versenyképes vagy mennyire képes exportálni rendkívüli állapot kihirdetésekor. Ezek a kockázatok, amelyek főként békeidőszakban és a felkészítés időszakában jelentkezhetnek, közvetetten később negatív hatással lehetnek a különleges jogrend időszaki igények kielégítésére (például nem a legmodernebb eszközöket, anyagokat gyártja az ipar, vagy az energiaszektorban lévő egyes vállalatok a külső importfüggőség miatt csak jelentős időeltolódással tudják biztosítani a szükséges készleteket). Ezért mindenképpen indokolt, hogy a felmerülő kockázatok beazonosítására és bekövetkezésük kezelésére legalább tervezés szintjén történjen előrelépés az érintett minisztériumoknál, amellyel bővíthetik a nemzetgazdaság védelmi felkészítésének és mozgósításának dokumentumait.

\section{FELHASZNÁLT IRODALOM}

131/2003. (VIII. 22.) Korm. rendelet a nemzetgazdaság védelmi felkészítése és mozgósítása feladatai végrehajtásának szabályozásáról. https://net.jogtar.hu/jogszabaly?docid=a0300131.kor

2011. évi CXIII. törvény a honvédelemről és a Magyar Honvédségről, valamint a különleges jogrendben bevezethető intézkedésekről. https://net.jogtar.hu/jogszabaly?docid=a1100113.tv

A honvédelmi miniszter 52/2020. (X. 8.) HM utasítása a hadfelszerelés rendszerbe kerülésének és rendszerből történő kivonásának rendjéröl. https://magyarkozlony.hu/dokumentumok/1ce0b56be d728b91 faaaeaa1c00934343bb6287c/megtekintes

A magyar-orosz gazdasági kapcsolatok a XXI. század elején. Statisztikai Tükör, Budapest, 2010. http:// www.ksh.hu/docs/hun/xftp/gyor/jel/jel31006.pdf

Ált/217. Magyar Honvédség Összhaderőnemi Logisztikai Támogatási Doktrína. 3. kiadás. Magyar Honvédség, Budapest, 2015.

Hacker, Barton C.: Marslakók új környezetben. Az amerikai katonai kutatás és fejlesztés szervezeti átalakitása. Fizikai Szemle, Budapest, 1997/3.

Horváth Attila: A katonai logisztika alapképzési szak RSOM felkészités tapasztalatai. Hadmérnök, 2018/4. http://hadmernok.hu/184_06_horvath.pdf

Kelly, Julie C. - Lago, Daniel E. - Thomason, James S.: Strengthening Industrial Base Decision-Making for Precision-Guided Munitions. Texas Security Review, 11. 08. 2020. https://warontherocks. com/2020/08/strengthening-industrial-base-decision-making-for-precision-guided-munitions/

Magyarország Alaptörvénye. https://net.jogtar.hu/jogszabaly?docid=a1100425.atv

Szajkó Gyula - Dr. Fábos Róbert: Gondolatok a katonai ellátási lánc fejlesztési lehetőségeiről. Katonai Logisztika, 2020/1-2.http://epa.oszk.hu/02700/02735/00091/pdf/EPA02735_katonai_logisztika 2020_01-02_151-181.pdf

Taksás Balázs: A hadiipar fejlesztésének feltételei és müködésének követelményei. Honvédségi Szemle, 148. évf. 2020/2. http://real.mtak.hu/107697/; DOI: 10.35926/HSZ.2020.2.12 